\title{
Cold induced changes on sugar contents and respiratory enzyme activities in coffee genotypes
}

\author{
Alterações dos teores de açúcares e da atividade de enzimas do metabolismo respiratório em \\ genótipos de café submetidos ao frio
}

\author{
Fábio Luiz Partelli ${ }^{\mathrm{I}}$ Henrique Duarte Vieira ${ }^{\mathrm{II}}$ Ana Paula Dias Rodrigues ${ }^{\mathrm{III}}$ Isabel Pais ${ }^{\mathrm{IV}}$ \\ Eliemar Campostrini ${ }^{\text {II }}$ Maria Manuela Coelho Cabral Chaves ${ }^{\text {III }}$ José Cochicho RamalhoV $^{\text {V }}$
}

\begin{abstract}
The present research aimed to characterize some biochemical responses of Coffea canephora (clones 02 and 153 ) and C. arabica (Catucaí IPR 102) genotypes subjected to low positive temperatures, helping to elucidate the mechanisms involved in cold tolerance. For that, one year old plants were subjected successively to 1) a temperature decrease $\left(0.5^{\circ} \mathrm{C}\right.$ a day) from $25 / 20^{\circ} \mathrm{C}$ to $13 / 8^{\circ} \mathrm{C}$ (acclimation period), 2) a three day chilling cycle $\left(3 \times 13 / 4^{\circ} \mathrm{C}\right)$ and to 3$)$ a recovery period of 14 days $\left(25 / 20^{\circ} \mathrm{C}\right)$. In Catucaí (less cold sensitive when compared to clone 02) there was an increased activity in the respiratory enzymes malate dehydrogenase and pyruvate kinase. Furthermore, Catucaí showed significant increases along the cold imposition and the higher absolute values after chilling exposure of the soluble sugars (sucrose, glucose, fructose, raffinose, arabinose and mannitol) that are frequently involved in osmoregulation and membrane stabilization/protection. The analysis of respiratory enzymes and of soluble sugar balance may give valuable information about the cold acclimation/ tolerance mechanisms, contributing to a correct selection and breeding of Coffea sp. genotypes.
\end{abstract}

Key words: coffee tree, Coffea sp., sucrose, enzymes, cold stress.

\section{RESUMO}

A pesquisa teve por objetivo caracterizar respostas bioquímicas de genótipos de Coffea canephora (clones 02 and 153) e C. arabica (Catucaí IPR 102) submetidos a baixas temperaturas positivas, ajudando a elucidar os mecanismos envolvidos na tolerância ao frio. Plantas com um ano de idade foram submetidas sucessivamente a 1) decréscimo da temperatura $\left(0,5^{\circ} \mathrm{C}\right.$ por dia) desde $25 / 20^{\circ} \mathrm{C}$ até $13 / 8^{\circ} \mathrm{C}$ (período de aclimatização), 2) um ciclo de três dias a $13 / 4^{\circ} \mathrm{C}$ e 3) 14 dias de recuperação $\left(25 / 20^{\circ} \mathrm{C}\right)$. Em Catucaí, genótipo menos sensível ao frio quando comparado com o clone 02, observouse um aumento das atividades das enzimas malato desidrogenase e piruvate cinase, relacionadas com a respiração. Nesse genótipo, os níveis de açúcares solúveis sacarose, glucose, frutose, rafinose, arabinose e manitol (frequentemente envolvidos em processos de regulação osmótica e estabilização/proteção de membranas) aumentam significativamente durante a imposição de baixas temperaturas, mostrando ainda os valores absolutos mais elevados depois de exposição a $4^{\circ} \mathrm{C}$. Portanto, a análise de enzimas respiratórias e do balanço de açúcares solúveis pode fornecer informação importante sobre mecanismos de aclimatização/tolerância ao frio, contribuindo para seleção e melhoramento de genótipos de Coffea sp.

Palavras-chave: cafeeiro, Coffea sp., sacarose, enzima, estresse de frio.

\section{INTRODUCTION}

The genus Coffea comprehends at least 103 species, with commercial relevance for $\boldsymbol{C}$. arabica and C. canephora (DAVIS et al., 2006). World's coffee production in the last years has being of more than 110 million sacks, produced essentially in developing countries (ICO, 2009). Brazil is the world's biggest coffee producer and exporter, and has in this culture an important source of incomes, employment and local development in the producing or processing regions.

'Escola de Agronomia e Engenharia de Alimentos, Universidade Federal de Goiás (UFG), Campus II Samambaia, CP 131, 74001970, Goiânia, GO, Brasil. E-mail: partelli@yahoo.com.br. Autor para correspondência.

"Universidade Estadual do Norte Fluminense Darcy Ribeiro (UENF), Campos dos Goytacazes, RJ, Brasil.

IIIInstituto Superior de Agronomia (ISA), Lisboa, Portugal.

${ }^{\mathrm{IV}}$ Instituto Nacional de Recursos Biológicos, Oeiras, Portugal.

${ }^{\mathrm{V}}$ Instituto de Investigação Científica Tropical, Oeiras, Portugal. 
Exposure to non-freezing temperature has a depressing effect on growth, photosynthetic performance and yield. Besides that, low temperatures can damage root system, with a consequent leaf death. Plants have mechanisms of cold acclimation that promote quantitative and qualitative modifications of membrane lipids, increased activity of antioxidant enzymes and increased ability to dissipate excess energy. In fact, the existence of different acclimation abilities within the Coffea genus seems to be related to the tolerance of the photosynthetic apparatus in face of oxidative stress conditions (RAMALHO et al., 2003). The presence of these mechanisms is essential for the implementation and maintenance of plant species in a region, influencing plant performance and agricultural practices, as well as the economical viability of the crop. Thus, this knowledge is important for the selection and management of the genus Coffea (PRAXEDES et al., 2006).

Growers and researchers believe that Conilon cultivation may be an alternative in such areas, once this species has a higher tolerance to biotic and abiotic stress than Arabic coffee, despite its higher susceptibility to low temperatures (RAMALHO et al., 2003). In this way, the objective of the present research was to contribute to the characterization of physiological and biochemical responses of Coffea canephora and C. arabica genotypes subjected to low positive temperatures, helping to elucidate the mechanisms involved in cold tolerance/sensitivity.

\section{MATERIAL AND METHODS}

One year old plants of Coffea canephora cv. 'Conilon': clone 02 (early ripening) and 153 (late ripening), and C. arabica cv. 'Catucaí IPR 102' were used for the experiments. Coffee plants were growth in pots containing 3L of substrate (soil:sand, 4:1 and organic plus chemical nutrients) in a greenhouse at the Center of Vegetal Ecophysiology, Biochemistry and Biotechnology from the Tropical Research Institute in Oeiras, Portugal.

Plants were transferred to growing chambers (walkin type, Fitoclima 1000 EHHF) with 700$900 \mu \mathrm{mol} \mathrm{m} \mathrm{m}^{-2} \mathrm{~s}^{-1}$ of irradiance, $\mathrm{CO}_{2}$ concentration of $380 \mu \mathrm{L} \mathrm{L}^{-1}, 70 \%$ relative humidity, $12 \mathrm{~h}$ photoperiod and $25 / 20^{\circ} \mathrm{C}$ (day/night) temperatures for a period of 15 days, in order to promote plant acclimation to this environmental conditions set as control. After that, plants were submitted to a gradual temperature reduction $\left(0.5^{\circ} \mathrm{C}\right.$ a day), from $25 / 20^{\circ} \mathrm{C}$ to $13 / 8^{\circ} \mathrm{C}$, during a 24 days period, in order to allow a gradual expression of the acclimating potential to low temperatures. After this period, plants were subjected to three consecutive chilling cycles at $4^{\circ} \mathrm{C}$ at night and in the first four hours of the next day and $13^{\circ} \mathrm{C}$ during day time $\left(3 \times 13 / 4^{\circ} \mathrm{C}\right)$, followed by a recovery period by raising the temperature to $20 / 15^{\circ} \mathrm{C}$ in the first day and to $25 / 20^{\circ} \mathrm{C}$ the following 13 days.

All analyses were performed in recently mature leaves under, at least, six conditions: 1) $25 / 20^{\circ} \mathrm{C}$ (control); 2) $18 / 13^{\circ} \mathrm{C}$ (half of the acclimation period); 3 ) $13 / 8^{\circ} \mathrm{C}$ (end of the acclimation period); 4 ) $3 \times 13 / 4^{\circ} \mathrm{C}$ (after three cycles of low positive temperature); 5) at $25 / 20^{\circ} \mathrm{C}$, seven and 14 days after the end of the low temperature exposure. Leaf material was collected after 2-2:30 minutes of illumination, from six to eight plants of each genotype, which were immediately frozen in liquid nitrogen and placed at $-80^{\circ} \mathrm{C}$ until analysis.

For measuring the activity of respiration key enzymes, four replicates of each samples $\left(2 \mathrm{~cm}^{-2}\right)$ were homogenized in a cooled mortar using 100mg PVPP (antioxidant) and $1 \mathrm{~mL}$ extraction buffer $100 \mathrm{mM}$ Tris$\mathrm{HCl}(\mathrm{pH} 8)$, containing $10 \mathrm{mM} \mathrm{MgCl}_{2}, 10 \mathrm{mM} \mathrm{NaHCO}_{3}$, $10 \mathrm{mM}$ ß-mercaptoethanol, 2mM DTT, 1\% (v/v) Triton X-100, "complete-protease inhibitor cocktail" $2 \%(\mathrm{v} / \mathrm{v})$ and $10 \%(\mathrm{v} / \mathrm{v})$ glycerol. Extracts were centrifuged $\left(16,000 \mathrm{~g}, 20 \mathrm{~min}, 4^{\circ} \mathrm{C}\right)$ and used for determination of enzymatic activity, based on NADH oxidation at 340nm and $21^{\circ} \mathrm{C}$, in a spectrophotometer UV-Vis (Bio-Rad Smart-3.000) (MAROCO et al., 1999). Enzymatic activity was calculated according to the following formula: Activity $=\left[\mu \mathrm{mol} \mathrm{NADH} \mathrm{m}{ }^{-2} \mathrm{~s}^{-1}=\mathrm{OD} /\right.$ seconds $x(1 / 6.22)$ $\mathrm{x}$ (total volume/sample volume)/fresh weight]; Where OD corresponds to the optical density obtained and 6.22 is the absorptive coefficient $\left(\varepsilon_{\mathrm{NADH}}\right)$.

For determination of the enzyme pyruvate kinase (PK) activity, de-ionized water was used in buffer $100 \mathrm{mM}$ Tris-HCl (pH 8), containing $10 \mathrm{mM} \mathrm{MgCl}$, $0.2 \mathrm{mM}$ NADH, $1 \mathrm{mM}$ frutose-1.6-phosphate, $45 \mathrm{mM}$ ADP, $6.3 \mathrm{UmL}^{-1}$ lactate dehydrogenase and $40 \mu \mathrm{L}$ of the over floating. Reaction was initiated with the addition of $1 \mathrm{mM}$ phosphoenolpiruvate (PEP) in $1 \mathrm{~mL}$ final volume. For the determination of the malate dehydrogenase (MDH) activity, a buffer $50 \mathrm{mM}$ Tris$\mathrm{HCl}$ (pH 8), containing $0.1 \mathrm{mMNADH}$ and $20 \mu \mathrm{L}$ extract, was used. Reaction was initiated with addition of $0.4 \mathrm{mM}$ oxalacetate, in a final volume of $1 \mathrm{~mL}$ (LÓPEZMILLÁM et al., 2000).

For soluble sugar determinations the analysis procedure was based on DAMESIN \& LELARGE (2003), after minor optimization modifications for coffee. Approximately $100 \mathrm{mg}$ of leaf material was homogenized in $2 \mathrm{~mL}$ pure cold water and $50 \mathrm{mg}$ PVPP, left with agitation $\left(20 \mathrm{~min}, 4^{\circ} \mathrm{C}\right)$ and centrifuged $(12,000 \mathrm{~g}$, $\left.5 \mathrm{~min}, 4^{\circ} \mathrm{C}\right)$. The supernatant was successively submitted to $100^{\circ} \mathrm{C}$ for $3 \mathrm{~min}$ in a water bath, placed in ice for $6 \mathrm{~min}$, centrifuged $\left(12.000 \mathrm{~g}, 15 \mathrm{~min}, 4^{\circ} \mathrm{C}\right)$ and 
filtered (nylon filter, $0.45 \mu \mathrm{m}$ ), before HPLC analysis. Aliquots of $80 \mu \mathrm{L}$ were injected in an HPLC (Waters, USA) equipped with a reafractometric detector (Waters 2414) and Sugar-Parkl column (Waters 300x6.5mm) in oven at $90^{\circ} \mathrm{C}$. Pure water, containing EDTA-Ca at $50 \mathrm{mg}$ $\mathrm{L}^{-1}$, was used as eluent, with $0.5 \mathrm{~mL} \mathrm{~min}^{-1}$ isocratic flow, for $22 \mathrm{~min}$. Sugar identification and quantification was performed using standards of known concentration.

Statistical analyses of data followed a completely randomized design, with four replicates. A two-way ANOVA $(\mathrm{P}<0.05)$ was applied to evaluate differences between temperatures and between genotypes, followed by a Tukey test for mean comparison ( $95 \%$ confidence level).

\section{RESULTS AND DISCUSSION}

It is known that the maintenance of respiratory metabolism is important once it allows energy production, redox capability and the synthesis of metabolic intermediaries that make possible metabolism in general, and processes of reparation in particular, under low temperature conditions. In coldsensitive plants, respiration is strongly affected due to the inhibition of several enzymes, which provokes an exponential decline of respiratory rates with decreasing temperatures (LARCHER, 1981). Photosynthesis is strongly suppressed in coffee leaves under temperatures below $18 / 13^{\circ} \mathrm{C}$ (RAMALHO et al., 2003) what would limit the ATP supply to cellular metabolism. However, the need of ATP for cellular processes may induce the increase of the respiratory rate, as observed by DAY \& LAMBERS (1983). In fact, the enzymatic activity of $\mathrm{MDH}$ and $\mathrm{PK}$ increased for temperatures below $18 / 13^{\circ} \mathrm{C}$ (Table 1), except in clone 153 for PK. Thus, considering that these enzymes are involved in glycolysis of the respiratory process, such significant activity increases during the exposure to low temperatures and in the following recovery period would allow higher energy availability for cellular metabolic processes, particularly in Catucaí and clone 02. However, differently from Catucaí, such increase in respiration did not mean a higher cold tolerance in clone 02. This suggests that, at least for some plants, such increased respiratory activity is not enough and could not be directly correlated with cold tolerance, as reported in Zea mays subjected to $5^{\circ} \mathrm{C}$ (RIBAS-CARBO et al., 2000).

Furthermore, the limitation of Pi availability in the chloroplast could provoke a reduction of photosynthesis in plants subjected to low temperatures, once a reduction in the enzymatic activity regulating sucrose content may occur, reducing sucrose concentration and increasing phosphate-sugars (SAGE, 1994). Such sucrose decrease was evident in the Conilon clones (Table 2), what could result from sucrose-P synthase (SPS) inhibition. In fact, the inability of fully activate SPS is amongst the factors that contributes to a poor photosynthetic performance and a higher cold sensitivity (STRAND et al., 1999). However, low Pi availability was reported to provoke decreases in PK and MDH (KIHARA et al., 2003), what is not the case in coffee leaves, thus suggesting that $\mathrm{Pi}$ levels were not limiting.

Carbohydrates are a major category of compatible solutes that include hexoses (mostly fructose and glucose), disaccharides (sucrose, trehalose), sugar alcohols (inositol, mannitol) and complex sugars (raffinose and stachyose), all of which accumulate during stress (MORSY et al., 2007). The contents of the major monosaccharides displayed strong changes upon cold exposure and in the period following the end of the stress (Table 2). There was an increment in the glucose and fructose contents at 13/ $8^{\circ} \mathrm{C}$ and $3 \times 13 / 4^{\circ} \mathrm{C}$ in Catucaí and clone 02 , as it was

Table 1 - Enzymatic activity ( $\mu \mathrm{mol} \mathrm{s}{ }^{-1} \mathrm{~g}^{-1}$ of dry matter) in leaves collected after two hours of illumination, in different genotypes of Coffea sp. submitted to a gradual decrease of temperature $\left(25 / 20^{\circ} \mathrm{C}\right.$ until $\left.13 / 8^{\circ} \mathrm{C}\right)$ during 24 days, three cycles at temperature of $13 / 4^{\circ} \mathrm{C}$ $\left(3 \times 13 / 4^{\circ} \mathrm{C}\right)$ and latter periods of recovery $(\mathrm{Rec})$ at $25 / 20^{\circ} \mathrm{C}$ (at the end of seven and 14 days).

\begin{tabular}{|c|c|c|c|c|c|c|c|}
\hline \multirow{2}{*}{ - } & \multirow{2}{*}{ Genotype } & \multicolumn{6}{|c|}{ - } \\
\hline & & $25 / 20^{\circ} \mathrm{C}$ & $18 / 13^{\circ} \mathrm{C}$ & $13 / 8^{\circ} \mathrm{C}$ & $3 \times 13 / 4^{\circ} \mathrm{C}$ & $7 \mathrm{Rec}$ & $14 \mathrm{Rec}$ \\
\hline $\mathrm{MDH}$ & Catucaí & $1.002 \mathrm{Ab}^{*}$ & $0.757 \mathrm{Ab}$ & $1.925 \mathrm{Aa}$ & $1.955 \mathrm{Aa}$ & $2.291 \mathrm{Aa}$ & $1.868 \mathrm{Aa}$ \\
\hline \multirow[t]{2}{*}{ VC: 19.79} & Clone 02 & $0.906 \mathrm{Abc}$ & $0.449 \mathrm{Ac}$ & $0.979 \mathrm{Bbc}$ & $1.353 \mathrm{Bb}$ & $1.036 \mathrm{Bb}$ & $1.929 \mathrm{Aa}$ \\
\hline & Clone 153 & 0.853 Acd & $0.639 \mathrm{Ad}$ & $1.026 \mathrm{Bbcd}$ & $1.252 \mathrm{Bbc}$ & $2.099 \mathrm{Aa}$ & $1.400 \mathrm{Bb}$ \\
\hline PK & Catucaí & $0.269 \mathrm{Abcd}$ & $0.251 \mathrm{Acd}$ & $0.360 \mathrm{Abc}$ & $0.394 \mathrm{Bb}$ & $0.540 \mathrm{Aa}$ & 0.199Ad \\
\hline \multirow[t]{2}{*}{ VC: 23.76} & Clone 02 & $0.158 \mathrm{Bc}$ & $0.166 \mathrm{Ac}$ & $0.211 \mathrm{Bbc}$ & $0.509 \mathrm{Aa}$ & $0.336 \mathrm{Bb}$ & $0.238 \mathrm{Abc}$ \\
\hline & Clone 153 & $0.216 \mathrm{ABa}$ & $0.178 \mathrm{Aa}$ & $0.236 \mathrm{Ba}$ & $0.176 \mathrm{Ca}$ & $0.284 \mathrm{Ba}$ & $0.202 \mathrm{Aa}$ \\
\hline
\end{tabular}

* Mean values within column followed by the same capital letter and by the same lower-case letter within line are not statistically different based upon Tukey's HSD means separation test at $P<0.05$.

$\mathrm{VC}=$ Variation coefficient. $\mathrm{MDH}=$ Malate dehidrogenase and $\mathrm{PK}=$ Pyruvate kinase 
Table 2 - Changes in the soluble sugars concentrations ( $\mathrm{mg} \mathrm{g}^{-1}$ of dry matter) in leaves collected after two hours of illumination in different genotypes of Coffea sp. submitted to a gradual decrease of temperature $\left(25 / 20^{\circ} \mathrm{C}\right.$ until $\left.13 / 8^{\circ} \mathrm{C}\right)$ during 24 days, three cycles at temperature of $13 / 4^{\circ} \mathrm{C}\left(3 \times 13 / 4^{\circ} \mathrm{C}\right)$ and latter periods of recovery $(\mathrm{Rec})$ at $25 / 20^{\circ} \mathrm{C}$ (at the end of seven and 14 days).

\begin{tabular}{|c|c|c|c|c|c|c|c|}
\hline \multirow{2}{*}{$\begin{array}{l}- \\
-\end{array}$} & \multirow{2}{*}{ Genotype } & \multicolumn{6}{|c|}{ 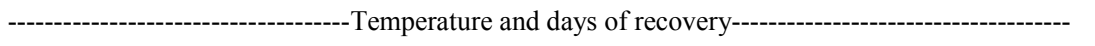 } \\
\hline & & $25 / 20^{\circ} \mathrm{C}$ & $18 / 13^{\circ} \mathrm{C}$ & $13 / 8^{\circ} \mathrm{C}$ & $3 \times 13 / 4^{\circ} \mathrm{C}$ & $7 \mathrm{Rec}$ & $14 \mathrm{Rec}$ \\
\hline Stachyose & Catucaí & $25.8 \mathrm{Ac}^{*}$ & $37.6 \mathrm{Ab}$ & $51.8 \mathrm{Aa}$ & $34.5 \mathrm{Bbc}$ & $32.4 \mathrm{Bbc}$ & $26.4 \mathrm{Bc}$ \\
\hline \multirow[t]{2}{*}{ VC: 14.97} & Clone 02 & $15.1 \mathrm{Bc}$ & $20.6 \mathrm{Bbc}$ & 28.6Bab & 26.6Bab & 25.9Bab & $33.3 \mathrm{Ba}$ \\
\hline & Clone 153 & 14.9Bd & $37.8 \mathrm{Ac}$ & $44.5 \mathrm{Abc}$ & $50.2 \mathrm{Aab}$ & $58.4 \mathrm{Aa}$ & 52.8Aab \\
\hline Raffinose & Catucaí & $23.2 \mathrm{Ac}$ & $27.8 \mathrm{Aabc}$ & 36.1Aa & $33.2 \mathrm{Aab}$ & 31.2Babc & $26.2 \mathrm{ABbc}$ \\
\hline \multirow[t]{2}{*}{ VC: 15.19} & Clone 02 & $28.4 \mathrm{Abc}$ & 28.1Abc & $30.2 \mathrm{Abc}$ & $23.8 \mathrm{Bc}$ & $41.8 \mathrm{Aa}$ & $32.7 \mathrm{Ab}$ \\
\hline & Clone 153 & $14.4 \mathrm{Bb}$ & $13.0 \mathrm{Bb}$ & $14.6 \mathrm{Bb}$ & $16.8 \mathrm{Cab}$ & $24.4 \mathrm{Ba}$ & $24.4 \mathrm{Ba}$ \\
\hline Sucrose & Catucaí & $47.9 \mathrm{Bbc}$ & $48.2 \mathrm{Bbc}$ & 40.5Acd & $54.2 \mathrm{Aab}$ & $36.6 \mathrm{Bd}$ & $61.2 \mathrm{Aa}$ \\
\hline \multirow[t]{2}{*}{ VC: 8.63} & Clone 02 & 71.9Aa & $59.1 \mathrm{Ab}$ & 42.4Ad & 43.4Bd & $54.4 \mathrm{Abc}$ & 49.0Bcd \\
\hline & Clone 153 & $74.3 \mathrm{Aa}$ & $51.8 \mathrm{ABb}$ & 42.0Ac & 47.3ABbc & $51.4 \mathrm{Ab}$ & $53.5 \mathrm{Bb}$ \\
\hline Glucose & Catucaí & $14.7 \mathrm{Ac}$ & $16.2 \mathrm{Ac}$ & 21.9Aa & 20.1Aab & $17.4 \mathrm{Bbc}$ & $17.6 \mathrm{Bbc}$ \\
\hline \multirow[t]{2}{*}{ VC: 10.54} & Clone 02 & $13.8 \mathrm{Ac}$ & $16.8 \mathrm{Abc}$ & 18.2Bab & 18.0Aab & $21.0 \mathrm{Aa}$ & 21.1Aa \\
\hline & Clone 153 & $6.03 \mathrm{Bc}$ & $6.70 \mathrm{Bc}$ & $6.38 \mathrm{Cc}$ & $8.63 \mathrm{Bbc}$ & $13.7 \mathrm{Ca}$ & $10.3 \mathrm{Cb}$ \\
\hline Fructose & Catucaí & 12.9Ad & 17.3Ac & $25.4 \mathrm{Ab}$ & 31.9Aa & $18.7 \mathrm{Bc}$ & 19.1Ac \\
\hline \multirow[t]{2}{*}{ VC: 6.87} & Clone 02 & 12.9Ac & $15.9 \mathrm{Ab}$ & $17.3 \mathrm{Bb}$ & $20.7 \mathrm{Ba}$ & 21.6Aa & $20.2 \mathrm{Aa}$ \\
\hline & Clone 153 & $8.89 \mathrm{Bc}$ & $8.61 \mathrm{Bc}$ & $8.51 \mathrm{Cc}$ & $10.7 \mathrm{Cbc}$ & $13.4 \mathrm{Ca}$ & $12.4 \mathrm{Bab}$ \\
\hline Arabinose & Catucaí & $5.39 \mathrm{ABc}$ & 7.46Ab & $7.88 \mathrm{Ab}$ & $11.3 \mathrm{Aa}$ & $10.9 \mathrm{Aa}$ & $8.13 \mathrm{Ab}$ \\
\hline \multirow[t]{2}{*}{ VC: 10.75} & Clone 02 & 4.62Bd & $5.73 \mathrm{Bcd}$ & 7.19Abc & $9.61 \mathrm{Ba}$ & $8.40 \mathrm{Bab}$ & $6.85 \mathrm{Abc}$ \\
\hline & Clone 153 & 5.94Aab & $4.53 \mathrm{Bb}$ & 4.95Bab & $6.31 \mathrm{Ca}$ & $6.47 \mathrm{Ca}$ & $5.16 \mathrm{Bab}$ \\
\hline Mannitol & Catucaí & $5.52 \mathrm{Bd}$ & 14.1Ac & $23.9 \mathrm{Ab}$ & 38.0Aa & $12.8 \mathrm{Bc}$ & $8.33 \mathrm{Cd}$ \\
\hline \multirow[t]{2}{*}{ VC: 9.06} & Clone 02 & $7.83 \mathrm{Be}$ & 9.81Bde & $12.6 \mathrm{Ccd}$ & $20.1 \mathrm{Bb}$ & $23.1 \mathrm{Aa}$ & $13.5 \mathrm{Bc}$ \\
\hline & Clone 153 & $10.6 \mathrm{Ac}$ & $14.3 \mathrm{Ab}$ & $15.0 \mathrm{Bb}$ & $18.0 \mathrm{Ba}$ & $10.5 \mathrm{Bc}$ & 16.1Aab \\
\hline
\end{tabular}

*Mean values within column followed by the same capital letter and by the same lower-case letter within line are not statistically different based upon Tukey's HSD means separation test at $P<0.05$. VC=Variation coefficient.

observed in C. dewevrei (RAMALHO et al., 2003). This was not the case in clone 153 , similarly to what has been observed in $\boldsymbol{C}$. canephora cv. Apoatã and $\boldsymbol{C}$. arabica cv. Icatu by RAMALHO et al. (2003). These data clearly shows different impacts of cold amongst genotypes. The increase of these hexoses may reflect a lower use by the cellular metabolism, but in case of clone 02 a sucrose synthesis inhibition (by an eventual inhibition of SPS), would also be involved once this sugar was consistently reduced. In Catucaí, the slight increase of sucrose concomitantly to the increase in glucose and fructose levels upon cold exposure, (the latter mostly resulting from a lower utilization rather than an increase of production, since photosynthesis was negligible at $13 / 8^{\circ} \mathrm{C}$ and upon chilling) could indicate a higher tolerance to cold. In fact, the maintenance or increase in sucrose content was shown to provide higher tolerance to plants under cold (PALONEN et al., 2008) and drought (PRAXEDES et al., 2006) stresses.

In clone 153, glucose and fructose contents were always smaller than in the other genotypes and were maintained under cold treatment, concomitantly with a sucrose decrease. Similar changes of sucrose content were also observed in water deficit sensitive clones of C. canephora cv. Conilon (PRAXEDES et al., 2006). To such sucrose reduction may have accounted the maintenance of sucrose translocation to other plant tissues, its degradation to monosaccharides, that in turn could be used in respiration (due to the increase of MDH and PK activities), or a reduced synthesis, once SPS could be sensitive to low temperatures (ALLEN \& ORT, 2001) and to water deficit (PRAXEDES et al., 2006).

Until the end of the experiment, 14 days after the end of chilling stress, the sucrose, glucose and fructose contents were quite different to their control values, suggesting incomplete recoveries for all genotypes, but in Catucaí a tendency to reach control values is clearer, especially regarding the hexoses.

The content of raffinose, a trisaccharide of galactose, fructose, and glucose, only increased significantly with the decrease in temperature in Catucaí (Table 2), approaching to control values after chilling exposure. This sugar may contribute to increased 
tolerance to low temperature, since it was associated to membrane stabilization. In fact, raffinose increase was reported in Oryza sativa (MORSY et al., 2007) cold tolerant plants when compared to the sensitive ones, as well as during the cold acclimation process (PALONEN et al., 2008).

Stachyose, a tetrasaccharide with two galactose, one glucose and one fructose molecules, increased gradually in all coffee genotypes under low temperatures, as also noted by TAPERNOUX-LÜTHI et al. (2004) in other plants. Such increases of stachyose and raffinose might be involved in the acclimation process to low temperatures, as suggested for Lonicera caerulea L. (IMANISHI et al., 1998). In this way, the highest values of both sugars in Catucaí at the end of the acclimation period $\left(13 / 8^{\circ} \mathrm{C}\right)$ would confer a better protection for the chilling exposure. Clone 153 presented also high contents of stachyose at $13 / 8^{\circ} \mathrm{C}$ and onwards, while clone 02 presented the higher value of raffinose by the $7^{\text {th }}$ day of recovery.

Concerning arabinose, a monosaccharide pentose sugar, increased levels were found following the cold treatment in clone 02 and Catucaí, doubling its values under chilling. The latter showed also systematically higher values during the experimental period. Arabinose (as well as hidroxiproline) is an important component of the glycoproteins that has an important structural role in the cell wall, being particularly necessary in acclimation conditions to low temperatures to maintain cell wall extensibility. Hence, an increase in arabinose may indicate an increase in extensine, as suggested by WEISER et al. (1990).

Mannitol, an hexose sugar alcohol, also increased in all studied genotypes with the reduction of temperature (Table 2), with Catucaí showing the highest percentage and absolute values changes at $13 / 8^{\circ} \mathrm{C}$ and $3 \times 13 / 4^{\circ} \mathrm{C}$. It must be noted that mannitol values presented in the coffee genotypes are quite high, particularly in Catucaí where it reached $70 \%$ of the sucrose value after the chilling exposure. In vascular plants, mannitol is synthesized from mannose-6phosphate through the action of an NADPH mannose6-phosphate reductase (M-6-PR) that catalyzes the conversion of mannose-6-phosphate to mannitol-1phosphate, followed by dephosphorylation. Mannitol synthesis may occur simultaneously with either sucrose or raffinose synthesis (STOOP et al., 1996), but in Catucaí all 3 sugars increased simultaneously. Some advantages have been suggested for plants that use mannitol as a photoassimilate and phloemtranslocated carbohydrate, due to a higher carbon use efficiency of mannitol metabolism that has a higher net ATP yield than the catabolism of an equal amount of sucrose. Furthermore, mannitol-producing plants exhibit a high degree of salt tolerance, due to its role of osmoregulator and osmoprotectant. Thus, under dehydration (which is often associated to cold stress) such plants will display a better tolerance by maintaining mannitol biosynthetic capability, whereas photosynthetic sucrose synthesis is largely suppressed (STOOP et al., 1996).

Therefore, Catucaí showed the higher absolute values and significant increases after the three cycles at $13 / 4^{\circ} \mathrm{C}$ (except for stachyose after chilling exposure) of the soluble sugars related with osmotic regulation and membrane stabilization and protection (MORSY et al., 2007), what may confer a higher cold acclimation ability, since the increase of cold tolerance could be associated to increases in the concentration of monosaccharides and sucrose (UEMURA \& STEPONKUS, 2003). This could be associated to the lower cold impact on photosynthesis observed in this genotype and therefore more efficient acclimation mechanisms to chilling (PALONEN et al., 2008).

The ability of response to environmental changes is a requisite for plant survival, with enzymatic and sugar content alterations in the plant tissues being important indicators of a species acclimation capacity (LÓPEZ-MILLÁM et al., 2000). In fact, among other responses, the ability to maintain production and consumption of carbohydrates, as well as stabilization of its levels, are very important for cold tolerance (ALLEN \& ORT, 2001).

\section{CONCLUSION}

Coffee genotypes under study showed sensibility to low temperatures, but with different tolerance and recovering abilities. In this way, the better ability to cope with cold stress of Catucaí IPR 102, when comparing to Conilon clones (especially with clone 02 ), may be associated, among other factors, to higher activities of MDH and PK respiratory related enzymes, what agrees with the hypothesis that the maintenance of respiratory activity is an important component of cold acclimation.

'Catucaí IPR 102' showed significant increases along the cold imposition and the higher absolute values after chilling exposure of all soluble sugars under study (except for stachyose). Those molecules are frequently involved in osmoregulation and membrane stabilization and protection and may have contributed to the acclimation process.

\section{ACKNOWLEDGMENTS}

The authors wish to thank Dr. Tumoru Sera for the Catucaí IPR 102 and Gabriel Burgarelli for the Conilon plant materials. Thanks also to the CAPES and UENF, for the scholarship. This research was partially supported by FCT and European Fund FEDER (through the projects POCTI/AGG/ 43101/2001 and PTDC/AGR-AAM/64078/2006). 


\section{REFERENCES}

ALLEN, D.J.; ORT, D.R. Impacts of chilling temperatures on photosynthesis in warm-climate plants. Trends in Plant Science, v.6, p.36-42, 2001. Available via dialog: <http:// www.citeulike.org/user/emaynard/article/5972545>. Accessed: 30 Nov. 2009. doi: 10.1016/S1360-1385(00)01808-2.

DAMESIN, C.; LELARGE, C. Carbon isotope composition of current-year shoots from Fagus sylvatica in relation to growth, respiration and use of reserves. Plant, Cell and Environment, v.26, p.207-219, 2003. Available via dialog: <http:// www3.interscience.wiley.com/journal/118877810/abstract $>$. Accessed: 30 Nov. 2009. doi: 10.1046/j.13653040.2003.00951.x.

DAVIS, A.P. et al. An annotated taxonomic conspectus of the genus Coffea (Rubiaceae). Botanical Journal of the Linnean Society, v.152, p.465-512, 2006. Available via dialog: <http://www3.interscience.wiley.com/journal/ 118580744/abstract>. Accessed: 30 Nov. 2009. doi: 10.1111/ j.1095-8339.2006.00584.x.

DAY, D.A.; LAMBERS, H. Regulation of sugar, amino acid and peptide plant membrane transporters. Physiologia Plantarum, v.58, p.155-160, 1983.

HOLADAY, A.S. et al. Changes in activities of enzymes of carbon metabolism in leaves during exposure of plants to low temperature. Plant Physiology, v.98, p.1105-1114, 1992.

ICO, International Coffee Organization. Trade statistics. Available via dialog: http://www.ico.org/coffee_prices.asp. Accessed: 21 Aug. 2009.

IMANISHI, H. et al. Accumulation of raffinose and stachyose in shoot apices of Lonicera caerulea L. during cold acclimation. Scientia Horticulturae, v.72, p.255-263, 1998. Available via dialog: <http://www.ingentaconnect.com/content/els/ 03044238/1998/00000072/ 00000003/art00129>. Accessed: 30 Nov. 2009. doi:10.1016/S0304-4238(97)00129-5.

KIHARA, T. et al. Alteration of citrate metabolism in cluster roots of white Lupin. Plant, \& Cell Physiology, v.44, p.901908, 2003. Available via dialog: <http://pcp.oxfordjournals.org/ content/vol44/issue9/index.dtl>. Accessed: 30 Nov. 2009. doi: $10.1093 / \mathrm{pcp} / \mathrm{pcg} 115$.

LARCHER W. Effects of low temperature stress and frost injury on plant productivity. In JOHNSON, C.B. (Ed.). Physiological processes limiting plant productivity. London: Butterworths, 1981. p.253-269.

LÓPEZ-MILLÁM, A. et al. Responses of sugar beet rots to iron deficiency. Changes in carbon assimilation and oxygen use. Plant Physiology, v.124, p.885-897, 2000. Available via dialog: <http://www.plantphysiol.org/cgi/content/abstract/ 124/2/885>. Accessed: 30 Nov. 2009. doi:10.1104/ pp.124.2.885.

MAROCO, J.P. et al. Photosynthetic acclimationot maize to growth under elevated of carbon dioxide. Planta, v.210; p.115$125,1999$.

MORSY, M. et al. Alteration of oxidative and carbohydrate metabolism under abiotic stress in two rice (Oryza sativa L.) genotypes contrasting in chilling tolerance. Journal of Plant Physiology, v.164, p.157-167, 2007. Available via dialog:
$<$ http://dx.doi.org/10.1016/j.jplph.2005.12.004>. Accessed: 30 Nov. 2009. doi: 10.1016/j.jplph.2005.12.004.

PALONEN, P. et al. Changes in carbohydrates and freezing tolerance during cold acclimation of red raspberry cultivars grown in vitro and in vivo. Physiologia Plantarum, v.110, p.393-401, 2008. Available via dialog: <http:// www3.interscience.wiley.com/journal/120799356/abstract $>$. Accessed: 30 Nov. 2009. doi: 10.1111/j.13993054.2000.1100314.x.

PRAXEDES, S.C. et al. Effects of long-term soil drought on photosynthesis and carbohydrate metabolism in mature robusta coffee (Coffea canephora Pierre var. kouillou) leaves. Environmental and Experimental Botany, v.56, p.263273, 2006. Available via dialog: <http://dx.doi.org/10.1016/ j.envexpbot.2005.02.008>. Accessed: 30 Nov. 2009. doi:10.1016/j.envexpbot.2005.02.008.

RAMALHO, J.C. et al. Cold acclimation ability and photosynthesis among species of the tropical Coffea genus. Plant Biology, v.5, p.631-641, 2003. Available via dialog: $<$ http://www.thieme-connect.com/ejournals/abstract/ plantbiology/doi/10.1055/s-2003-4688>. Accessed: 30 Nov. 2009. doi: $10.1055 / \mathrm{s}-2003-44688$.

RIBAS-CARBO, M. et al. The electron partitioning between the cytochrome and alternative respiratory pathways during chilling recovery in two cultivars of maize differing in chilling sensitivity. Plant Physiology, v.122, p.199-204, 2000. Available via dialog: <http://www.plantphysiol.org/cgi/content/ abstract/122/1/199>. Accessed: 30 Nov. 2009. doi:10.1104/ pp.122.1.199.

SAGE, R.F. Acclimation of photosynthesis to increasing atmospheric $\mathrm{CO}_{2}$ : the gas exchange perspective. Photosynthesis Research, v.39, p.351-368, 1994. Available via dialog: <http:// www.springerlink.com/content/g86655j665860879>. Accessed: 30 Nov. 2009. doi: 10.1007/BF00014591.

STOOP, J.M.H. et al. Mannitol metabolism in plants: a method for coping with stress. Trends in Plant Science, v.1, p.139144, 1996.

STRAND, A. et al. Acclimation of Arabidopsis leaves developing at low temperatures. Increasing cytoplasmic volume accompanies increased activities of enzymes in the Calvin cycle and in the sucrose-biosynthesis pathway. Plant Physiology, v.119, p.1387-1397, 1999.

TAPERNOUX-LÜTHI, E.M. et al. Cloning, functional expression, and characterization of the raffinose oligosaccharide chain elongation enzyme, galactan:galactan galactosyltransferase, from common bugle leaves. Plant Physiology, v.134, p.1377-1387, 2004. Available via dialog: <http://www.plantphysiol.org/cgi/content/abstract/134/4/ 1377>. Accessed: 30 Nov. 2009. doi: 10.1104/pp.103.036210.

UEMURA, M.; STEPONKUS, P.L. Modification of the intracellular sugar content alters the incidence of freeze-induced membrane lesions of protoplasts isolated from Arabidopsis thaliana leaves. Plant Cell \& Environment, v.26, p.10831096, 2003.

WEISER, R.L. et al. Cell wall and extensin mRNA changes during cold acclimation of pea seedlings. Plant Physiology, v.93, p.1021-1026, 1990. Available via dialog: <http:// www.plantphysiol.org/cgi/content/abstract/93/3/1021>. Accessed: 30 Nov. 2009. 